\title{
KAJIAN PENYELENGGARAAN PAUD DI KOTA BANJARMASIN DITINJAU DARI ASPEK PERENCANAAN
}

\author{
STUDY ON THE IMPLEMENTATION OF EARLY CHILDHOOD EDUCATION IN THE \\ CITY OF BANJARMASIN VIEWED FROM THE ASPECTS OF PLANNING
}

\author{
Lisna Sulinar Sari \\ Pusat Penelitian Kebijakan Pendidikan dan Kebudayaan, Balitbang Kemdikbud \\ lisnapuslit@gmail.com
}

Naskah diterima: 17/05/2016, direvisi akhir: 30/05/2016, disetujui: 15/06/2016

\begin{abstract}
Abstrak: Permasalahan dalam penelitian ini yaitu dari jumlah lembaga PAUD yang ada di Kota Banjarmasin belum semuanya memiliki perencanaan khususnya pada analisis peningkatan legalitas kelembagaan PAUD dan analisis kebutuhan pendidikan untuk anak usia dini (AUD). Penelitian ini menggunakan pendekatan studi kasus dengan analisis data deskrtif kuantitatif dan kualitataif. Hasil studi menunjukkan bahwa: i) Disdik Kota Banjarmasin dan Lembaga PAUD sampel tidak melakukan perencanaan yang baik untuk pendataan analisis kebutuhan pendidikan AUD; ii) Belum semua lembaga PAUD sampel memiliki izin operasional dikarenakan adanya persyaratan yang belum dapat dipenuhi karena memerlukan biaya yang cukup besar seperti, pembuatan akta notaris; iii) Belum semua lembaga PAUD memiliki sarpras sesuai dengan pedoman sarana dan prasarana dari pusat; iv) untuk membantu ketersediaan sarpras, Disdik Kota Banjarmasin sudah mengalokasikan dana APBD II berupa bantuan RKB, rehab kelas rusak ringan dan berat, serta bantuan APE Dalam dan Luar berupa barang.
\end{abstract}

Kata kunci: Lembaga PAUD, perencanaan, izin operasional, sarana prasarana

Abstract: The problem in this study is from the number of early childhood institutions in the city of Banjarmasin not all have plans in particular to the analysis of institutional legality increase early childhood education and educational needs analysis for early childhood (AUD). This study uses a case study approach to data analysis of quantitative and qualitative deskrtif. The study shows that: i) Disdik Banjarmasin and Institutions ECD sample is not doing better planning for data analysis AUD educational needs; ii) Not all the samples of early childhood institutions have an operating permit because of the requirements can not be met because it requires significant costs such as notary deed; iii) Not all early childhood institutions have infrastructure accordance with the guidelines of the central infrastructure; iv) to assist the availability infrastructure, Disdik Banjarmasin already allocated budget II in the form of classroom assistance, rehabilitation of damaged light and heavy classes, as well as the In and Out APE assistance in the form of goods.

Keywords: Institution ECD, planning, operational permits, infrastructure 
PENDAHULUAN

Amandemen Undang-undang Dasar 1945 Republik Indonesia Tahun 1945 pada Bab XIII, Pasal 31, Butir 1 yang mengamanatkan bahwa, "Setiap warga negara berhak mendapatkan pendidikan". Hal tersebut mengindikasikan bahwa pendidikan itu dapat dilaksanakan mulai manusia lahir sampai akhir hayat dengan kata lain bahwa pendidikan dapat dilaksanakan sepanjang hayat (0 tahun sampai wafat).

Oleh sebab itu pendidikan sebaiknya diberikan sejak dini, karena pada usia dini perkembangan otak cepat berkembang, sinapsinap yang ada pada otak akan terhubung satu dengan lainnya apabila mendapatkan stimulasi yang baik dan benar. Namun, jika anak usia dini tidak mendapatkan stimulasi yang baik dan benar maka sinap-sinap yang ada malah akan terputus dan ini membawa dampak pada perkembangan anak menjadi tidak optimal dan pada pendidikan selanjutnya.

Dalam Undang-undang Republik Indonesia Nomor 20 Tahun 2003 tentang Sistem Pendidikan Nasional (Sisdiknas), Pasal 1, Butir 14 menyatakan bahwa "Pendidikan anak usia dini (PAUD) adalah suatu upaya pembinaan yang ditujukan kepada anak sejak lahir sampai dengan usia enam tahun yang dilakukan melalui pemberian rangsangan pendidikan untuk membantu pertumbuhan dan perkembangan jasmani dan rohani agar anak memiliki kesiapan dalam memasuki pendidikan lebih lanjut.” Bentuk penyelenggaraan PAUD terdapat pada Undang-undang Sisdiknas Pasal 28, Butir 2 sampai 5 menjelaskan bahwa," PAUD dapat diselenggarakan melalui jalur pendidikan formal, nonformal, dan/atau informal; Pendidikan anak usia dini pada jalur pendidikan formal berbentuk Taman Kanakkanak (TK), Raudatul Athfal (RA), atau bentuk lain sederajat; Pendidikan anak usia dini pada jalur pendidikan nonformal berbentuk Kelompok Bermain (KB), Taman Penitipan Anak (TPA), atau bentuk lain sederajat; Pendidikan anak usia dini pada jalur pendidikan informal berbentuk pendidikan keluarga atau pendidikan yang diselenggarakan oleh lingkungan”.

Penyelenggaraan PAUD di Kota Banjarmansin cukup berkembang dengan baik. Total lembaga PAUD pada tahun 2014 di Kota Banjarmasin yaitu 509 lembaga dengan total siswa yang sudah terlayani sebanyak 12.017 peserta didik. Agar penyelenggaraan PAUD dapat berjalan sesuai dengan yang diharapkan maka perlu adanya perencanaan. Perencanaan dibuat sebagai dasar/pedoman untuk mencapai tujuan yang telah ditentukan. Sedangkan agar lembaga PAUD diakui secara hukum dan pemerintah, maka pengelola PAUD harus mengajukan izin pendirian dan operasional ke Disdik Kota Banjarmasin, bahkan ada di daerah lain masalah perizinan apapun dijadikan satu pintu yaitu dinas perizinan terpadu. Untuk memperoleh izin tersebut ada beberapa persyaratan yang harus dipenuhi oleh lembaga PAUD. Persyaratan 
izin pendirian dan izin operasional tersebut dikeluarkan oleh Direktorat Pembinaan PAUD dan dikembangkan oleh masing-masing dinas pendidikan kabupaten/kota.

Dalam penyelenggaraan PAUD hal lain yang terkait dalam perencanaan ialah masalah pendidik dan tenaga kependidikan (PTK), sarana, prasarana, dan dana. Semua aspek itu saling berkaitan satu dengan lainnya dalam menunjang terselenggaranya layanan PAUD. Namun apakah semua lembaga PAUD di Kota Banjarmasin sudah memiliki sarana dan prasarana sesuai standar.

Rumusan permasalahan yang dapat diambil berdasarkan uraian di atas yaitu bagaimana perencanaan ditingkat lembaga PAUD dan Disdik Kota Banjarmasin. Apa saja persyaratan yang harus dipenuhi oleh lembaga PAUD untuk mendapatkan izin pendirian dan operasional. Selain itu kendala terbesar apa untuk memenuhi persyaratan perizinan tersebut. Serta upaya apa yang dilakukan oleh Disdik Kota Banjarmasin agar semua lembaga dapat memperoleh izin pendirian dan operasional.

Tujuan dari penelitian ini adalah untuk mengetahui: (i) Perencanaan di tingkat Lembaga PAUD, (ii) Perencanaan ditingkat Disdik Kota Banjarmasin, (iii) Upaya Disdik Kota Banjarmasin untuk meningkatkan penyelenggaraan PAUD.

Lingkup penelitian ini adalah semua lembaga PAUD yang ada di Kota Banjarmasin kecuali TPA, baik negeri maupun swasta. Indikator perencanaan hanya membahas mengenai legalitas lembaga PAUD dan ketersediaan sarana prasarana yang terdiri dari prasarana utama dan penunjang, serta sarana yang terdiri dari media pembelajaran, sumber belajar, APE Dalam dan Luar.

\section{KAJIAN PUSTAKA}

\section{Perencanaan}

Dalam menyelenggarakan suatu lembaga pendidikan, dibutuhkan suatu usaha pengelolaan yang baik. Mengelola lembaga pendidikan bukanlah suatu pekerjaan yang mudah, karena harus memikirkan semua aspek yang terlibat didalamnya. Masalah bisa saja muncul setiap saat, mulai dari kesiapan pendidik dan tenaga kependidikan, sarana prasarana, materi, tujuan bahkan sampai pada penyiapan proses pembelajaran. Agar penyelenggaraan pendidikan dapat berjalan dengan baik perlu adanya perencanaan yang baik. Perencana dapat dijadikan sebagai pedoman dalam menentukan arah dan tujuan penyelenggaraan pendidikan secara maksimal.

Perencanaan merupakan suatu proyeksi tentang apa yang harus dilaksanakan guna mencapai sasaran dan tujuan yang telah ditetapkan (Kaufman 1972; Hadikumoro 1980; Manap 2013). Sa'ud (2011; dalam Sigit Dwi Handoko, 2014) menyebutkan bahwa perencanaan pendidikan harus mengutamakan nilai-nilai manusiawi, karena pendidikan itu membangun manusia yang harus mampu membangun dirinya dan masyarakatnya. Berdasarkan defini di atas dapat ditarik 
kesimpulan bahwa perencanaan yaitu proyeksi tentang apa yang harus dilaksanakan untuk mencapai sasaran dan tujuan dengan mengutamakan nilai-nilai kemanusiaan.

Menurut M.A. Mukhyi (1991) bentuk perencanaan dapat dibedakan menjadi: (i) Rencana global (Global Plan), yaitu rencana yang berisi tentang penentuan tujuan organisasi secara menyeluruh, apa yang menjadi tujuan akhir suatu organisasi yang bersifat jangka panjang. Tujuan global ini dapat menjadi sebagai misi suatu organisasi; (ii) Rencana Strategik (Strategic Plan), adalah bagian dari rencana global yang lebih terperinci yaitu dengan menyusun rencana kerja untuk mencapai rencana global yang dimensi waktunya adalah jangka panjang. Pencapaian tujuan dilakukan dengan sistem priorotas, yaitu mana yang akan dicapai terlebih dahulu; (iii) Rencana Operasional (Operational Plan) merupakan penjabaran dari perencanaan strategik, adapun bentuk dari perencanaan ini berupa anggaran dan prinsipprinsip operasional. Ada dua bentuk rencana operasional: (i) Rencana sekali pakai (single use plan), yaitu kegiatan yang tidak digunakan lagi setelah tercapainya tujuan dan sifatnya lebih terperinci; (ii) Rencana tetap (standing plan), yaitu berupa pendekatan-pendekatan standar untuk penanganan situasi yang dapat diperkirakan terlebih dahulu dan akan terjadi berulang-ulang.

\section{Perizinan Pendirian dan Operasional Penyelenggaraan PAUD.}

Berdasarkan peraturan Menteri Pendidikan dan Kebudayaan Republik Indonesia Nomor 84 Tahun 2014 tentang Pendirian Satuan PAUD, Pasal 1, Ayat 2, dijelaskan bahwa, " Pendirian satuan PAUD adalah proses atau cara mendirikan satuan PAUD sesuai dengan persyatan yang ditentukan. Pada Pasal 2 disebutkan bahwa, "Satuan PAUD dapat didirikan oleh: a. pemerintah kabupaten/kota; b. pemerintah desa; c. orang perorangan; d. kelompok orang; atau e. badan hukum.

Pasal 4, Butir 1 menjelaskan tentang persyaratan pendirian TK/TKLB terdiri dari: a. persyaratan administratif; dan b. pesyaratan teknis; Ayat 2, menjelaskan persyaratan administratif pendirian TK/TKLB terdiri atas: a. Fotocopi indentitas pendiri; b. Surat keterangan domisili dari kepala desa/lurah; c. susunan pengurus dan rincian tugas; Ayat 3 menjelaskan persyaratan teknis pendirian TK/TKLB yang terdiri dari: a. Hasil penilaian kelayakan; b. Rencana Induk Pengembangan (RIP) TK/TKLB; c. Rencana pencapaian standar penyelenggaraan TK/TKLB paling lama 3 (tiga) tahun. Ayat 4, menyatakan bahwa, "Hasil penilaian kelayakan sebagaimana dimaksud pada ayat (3) huruf a meliputi: a. Dokumen hak milik, sewa, atau pinjam pakai atas tanah dan bangunan yang akan digunakan untuk penyelenggaraan TK/TKLB yang sah atas nama pendiri; $b$. Fotocopi akta notaris dan surat penetapan 
badan hukum dalam bentuk yayasan, perkumpulan, atau badan lain sejenis dari kementerian bidang hukum atas nama pendiri atau induk organisasi pendiri disertai surat keputusan yang menunjukan adanya hubungan dengan organisasi induk; dan c. Data mengenai perkiraan pembiayaan untuk kelangsungan TK/TKLB paling sedikit untuk 1 (satu) tahun pembelajaran". Butir 5 menyatakan bahwa, "RIP TK/TKLB sebagaimana dimaksud pada ayat (3) huruf b memuat: a. visi dan misi; b. Kurikulum tingkat satuan pendidikan (KTSP); c. sasaran usia peserta didik; d. Pendidik dan tenaga kependidikan; e. sarana dan prasarana; f. Sturktur organsisasi; g. Pembiayaan; h. Pengelolaan; i. Peran serta masyarakat; dan j. Rencana pentahapan pelaksanaan pengembangan selama 5 (lima tahun). Ayat 6 menjelaskan bahwa, “ Dokumen rencana pencapaian standar penyelenggaraan TK/TKLB sebagaimana dimaksud pada Ayat (3) huruf c didasarkan pada standar PAUD yang ditetapkan Menteri”.

Sedangkan Pasal 5, Ayat 1 menjelaskan persyaratan pendirian KB/TPA/SPS yang terdiri: a. Persyaratan administratif; dan b. Persyaratan teknis. Ayat 2 menjelaskan persyaratan administratif pendirian KB/TPA/SPS terdiri dari: a. Fotocopi identitas pendiri; b. Surat keterangan domisili dari kepala desa/lurah; c. Susunan pengurus dan rincian tugas. Ayat 4 Menjelaskan persyaratan teknis pendirian KB/TPA/SPS yang terdiri dari: a. Hasil penilaian kelayakan; b. Rencana pencapaian standar penyelenggaraan KB/TPA/SPS paling lama 5 (lima) tahun. Ayat 4 menjelaskan Hasil penilaian kelayakan sebagimana dimaksud pada Ayat (3) huruf a, meliputi: a. Dokumen hak milik, sewa, atau pinjam pakai atas tanah dan bangunan yang digunakan untuk menyelenggarakan KB/TPA/SPS yang sah atas nama pendiri; $b$. Dalam hal pendiri adalah badan hukum, wajib melampirkan fotocopi akta notaris dan surat penetapan badan hukum dalam bentuk yayasan, perkumpulan, atau badan lain sejenis dari kementerian bidang hukum atas nama pendiri atau induk organisasi pendiri disertai surat keputusan yang menunjukkan adanya hubungan dengan organisasi induk; c. Data mengenai perkiraan pembiayaan untuk kelangsungan KB/TPA/SPS paling sedikit untuk 1 (satu) tahun pembelajaran.

Pada Pasal 6 menyatakan bahwa, "Pendirian satuan PAUD yang diselenggarakan oleh pemerintah kabupaten/kota ditetapkan oleh bupati/walikota atas usul kepala dinas sesuai dengan peraturan perundang-undangan. Sedangkan Pasal 7 menjelaskan mekanisme pendirian satuan PAUD oleh pemerintah desa, orang perorangan, kelompok orang, atau badan hukum sebagai berikut: a. Pendiri satuan PAUD mengajukan permohonan izin pendirian kepada kepala dinas atau kepala SKPD melalui kepala dinas atau pejabat yang ditunjuk dengan melampirkan persyaratan pendirian satuan PAUD; b. Kepala Dinas atau pejabat yang ditunjuk sebagaimana dimaksud 
pada huruf a menelaah permohonan pendirian satuan PAUD berdasarkan kelengkapan persyaratan pemohon dengan memperhatikan hal-hal sebagai berikut: 1) data mengenai perimbangan antara jumlah TK/TKLB, KB, TPA, dan/atau SPS yang telah ada dan yang akan didirikan dengan jumlah penduduk usia sasaran yang akan dilayani di wilayah tersebut; 2) data mengenai perkiraan jarak TK/TKLB, KB, TPA, dan/atau SPS yang akan didirikan di antara TK/TKLB, KB, TPA, dan/atau SPS terdekat; 3) data mengenai daya tampung dan lingkungan jangkauan TK/TKLB, KB, TPA, dan/atau SPS yang akan didirikan per usia yang dilayani; 4) ketentuan penyelenggaraan satuan PAUD ditetapkan oleh pemerintah provinsi dan/atau pemerintah kabupaten/kota; c. Berdasarkan hasil telaahan sebagaimana dimaksud pada huruf b, kepala dinas: 1) memberi persetujuan atau penolakan atas permohonan izin pendirian satuan PAUD; atau 2) memberi rekomendasi kepada kepala SKPD atas permohonan izin pendirian satuan PAUD; d. Kepala dinas atau kepala SKPD menerbitkan keputusan izin pendirian satuan PAUD paling lama 60 hari sejak permohonan diterima kepala dinas. Sedangkan Pasal 8 menyatakan bahwa, "Izin pendirian satuan PAUD sebagaimana dimaksud dalam Pasal 6 dan Pasal 7 huruf d berlaku sampai dengan adanya pencabutan izin".

\section{Sarana dan Prasarana}

Sarana PAUD adalah seperangkat bahan dan media belajar untuk mendukung kegiatan belajar melalui bermain, sehingga menjadi lebih efektif dalam rangka mengoptimalkan perkembangan anak. Sedangkan prasarana pendidikan PAUD ialah segala macam alat, perlengkapan, atau benda-benda yang mendukung penyelenggaraan kegiatan pendidikan, pengasuhan, dan perlindungan anak usia dini secara optimal.

Fungsi sarana PAUD antara lain: 1) sebagai alat untuk mengoptimalkan seluruh aspek perkembangan anak; 2) sebagai pendukung terselenggaranya kegiatan bermain anak; 3) sebagai alat bantu dalam mempermudah penyampaian materi belajar kepada anak. Fungsi prasarana yaitu: 1) melengkapi lingkungan main dengan prasarana yang tepat untuk anak; 2) mendukung kelancaran proses belajar anak di lembaga PAUD; 3) meningkatkan efisiensi dan efektivitas penyelenggaraan PAUD dengan penempatan prasarana yang tepat; 4) mengembangkan karakter positif anak.

Jenis sarana dilihat dari proses pembuatannya terdiri dari: 1) Pabrikan yaitu sarana yang sudah tersedia/dibeli di toko-toko mainan; 2) Dibuat sendiri, sarana bermain yang dibuat sendiri oleh pendidik atau orang tua, terbuat dari bahan-bahan yang ada di sekitar lingkungan dan dari bahan-bahan bekas yang layak dipakai; 3) Tersedia di alam, yaitu sarana bermain yang memanfaatkan bahan alam yang tersedia di lingkungan sekitar. Jika dilihat dari fungsinya sarana PAUD dibedakan menjadi: 1) Bahan belajar, yaitu segala bentuk informasi yang disediakan pendidik berupa 
isi/pesan dalam buku maupun non buku yang dapat dipelajari anak pada saat mereka bermain/belajar, baik direncanakan maupun tidak; 2) Media belajar, ialah sarana fisik untuk menyampaikan bahan belajar sehingga dapat merangsang pikiran, perasaaan dan tindakan dalam rangka menumbuhkan motivasi anak untuk belajar. Media belajar berupa, alat permainan edukatif (APE), alat peraga edukatif, dan literatur.

Sedangkan prasarana terbagi menjadi prasarana utama yang terdiri dari, area kegiatan/bermain anak, ruang pendidik, ruang administrasi/ruang pimpinan/kepala sekolah/pengelola, ruang pemeriksaan kesehatan, kamar mandi anak dan dewasa, dan meubel. Prasarana penunjang terdiri dari dapur, area ibadah, ruang perpustakaan, ruang konsultasi, area parkir, ruang serbaguna, area cuci, gudang, dan jaringan telekomunikasi dan IT.

\section{Hasil Penelitian tentang Perencanaan PAUD}

Hasil penelitian Puslitjak (2014) menunjukan bahwa analisa kebutuhan dan kecukupan PAUD secara menyeluruh belum dilakukan oleh Dinas pendidikan kabupaten/kota sampel. Pengembangan PAUD dilaksanakan masih bersifat bottom up, yaitu hanya berdasarkan atau mengikuti aspirasi keinginan masyarakat yang ingin mendirikan lembaga PAUD. Sedangkan dinas pendidikan kabupaten/kota sampel belum melaksanakan perencanaan pembangunan
PAUD dan pemetaan PAUD yang bersifat top down. Sebagian kecil lembaga PAUD masih belum memiliki legalitas kelembagaan. Hal tersebut disebabkan oleh persyaratan perizinan yang belum terpenuhi atau sedang dalam proses perizinan dari dinas pendidikan setempat. lembaga PAUD masih belum melakukan analisis kebutuhan layanan pendidikan anak usia dini. Umumnya lembaga PAUD tidak melakukan pendataan terhadap keberadaan jumlah anak usia dini di lingkungan mereka berada, data tersebut diperoleh dari Posyandu. Lembaga PAUD umumnya telah memenuhi aspek legalitas, karena sebagian besar lembaga PAUD yang menjadi sampel telah memiliki izin operasional dan akte notaris. Hampir seluruh lembaga PAUD mengungkapkan bahwa mereka telah membuat perencanaan sarana prasarana, perencanaan pembiayaan, dan perencanaan kurikulum.

Hasil kajian dari Sigit Dwi Handoko dan Acmad Rifa'i (2014) tentang perencanaan program Pos PAUD Cinta Ibu dengan indikator tujuan perencanaan penyelenggaraan program Pos PAUD Cinta Ibu yaitu (1) memberikan layanan pendidikan anak usia dini yang berbasis kemasyarakatan, (2) memberikan pengetahuan bagi orangtua, (3) mengisi waktu luang dengan kegiatan yang postif bagi orangtua dan anak. Hal tersebut, dikarenakan Pos PAUD didirikan oleh masyarakat yaitu ibu-ibu Posyandu atau ibuibu PKK yang perduli terhadap PAUD. 
Salah satu hasil kajian dari Hiryanto, dkk, faktor pendukung pencapaian mutu pendidikan anak usia dini adalah: meningkatnya kesadaran masyarakat akan pentingnya pendidikan anak usia dini, gencarnya sosialiasi yang dilakukan oleh pemerintah, sedangkan yang menjadi faktor penghambat antara lain: keterbatasan pendanaan, kurangnya pengetahuan yang dimiliki oleh pendidik terkait dengan pendidikan anak usia dini, rendahnya partisipasi masyarakat di bidang pendidikan anak usia dini, khususnya pada PAUD yang di perdesaan. Hasil penelitian lainnya yaitu, penelitian Arri Handayani, dkk, (2011), menyimpulkan bahwa: (1) Terjadi peningkatan kualitas Pos PAUD melalui program holistik integratif dari siklus I ke siklus II; (2) Terjadi peningkatan kualitas pembelajaran pendidik PAUD melalui pelatihan; (3) Setelah dilakukan penelitian tindakan, dapat disimpulkan bahwa Pelatihan program PAUD holistik integratif dapat meningkatkan kualitas Pos PAUD.

\section{Kerangka Berpikir Kajian}

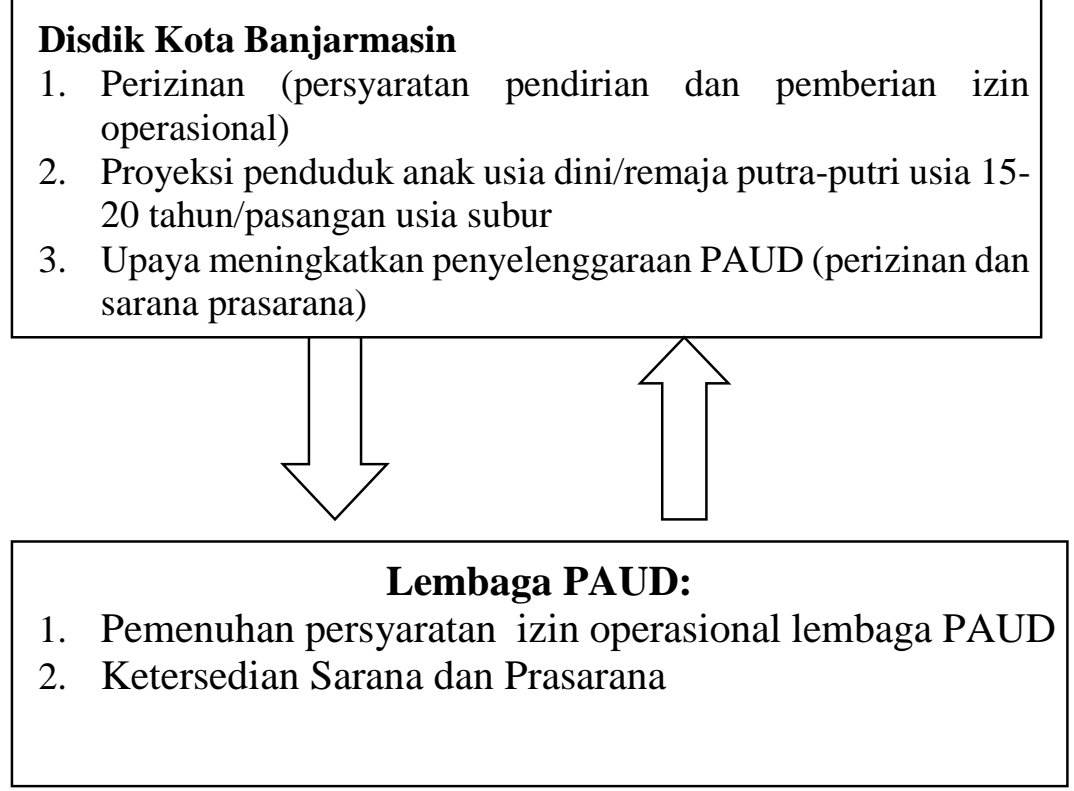

\section{Metode Penelitian}

Pendekatan penelitian ini berupa studi kasus yang ditujukan untuk menggambarkan perencanaan yang terdapat di tingkat lembaga PAUD dan Disdik dalam peningkatan penyelenggaraan PAUD di Kota Banjarmasin. Selain itu untuk menggambarkan proses perizinan pendirian dan operasional lembaga
PAUD serta kepemilikan sarana prasarana di lembaga PAUD sampel. Penelitian ini dilaksanakan pada Tahun 2014 di Kota Banjarmasin. Sampel lembaga PAUD terdiri dari Taman Kanak-kanak (TK), Kelompok Bermain (KB), dan Satuan PAUD Sejenis (SPS). Adapun yang menjadi sumber data adalah pejabat dinas pendidikan yang 
menangani PAUD, Penilik PAUD, Pengelola/penyelenggara PAUD, dan Pendidik PAUD di Kota Banjarmasin.

Teknik pengumpulan data dalam penelitian ini menggunakan data primer yang diperoleh dari pengisian kuesioner, diskusi kelompok, dan wawancara. Instrumen yang digunakan yaitu pedoman waawancana, diskusi, dan kuesioner. Teknik analisis data yang digunakan yaitu deskriptif kuantitatif dan kualitatif. Data yang kuantitatif dicocokan dengan persyaratan perizinan pendirian dan izin operasional lembaga PAUD yang terdapat di Permendikbud dan Kota Banjarmasin lalu diolah dan dianalisis, begitu pula dengan data kualitatif, jawaban hasil wawancara dan diskusi dikelompokkan setelah itu dianalisis.

\section{HASIL DAN PEMBAHASAN}

\section{Gambaran Lembaga PAUD di Kota Banjarmasin}

Kota Banjarmasin merupakan Ibu Kota Provinsi Kalimantan Selatan. Kota Banjarmasin dijuluki sebagai Kota seribu sungai yang merupakan kota kepulauan sebab terdiri dari kurang lebih 25 buah pulau kecil (delta) yang bagian-bagian kotanya dipisahkan oleh sungai-sungai. Kota Banjarmasin memiliki luas wilayah kurang lebih $98,46 \mathrm{~km}^{2}$ dan terletak pada $3^{0} 16^{\prime} 46$ " sampai dengan $3^{0} 22$ '54" Lintang Selatan dan 114031'40" sampai dengan 114039'55" Bujur Timur. (Banjarmasin dalam Angka 2015) Kota Banjarmasin memiliki lima kecamatan yang terdiri dari: 1) Kecamatan Banjarmasin Barat, 2) Banjarmasin Selatan, 3) Banjarmasin Tengah, 4) Banjarmasin Timur, dan 5) Banjarmasin Utara.

Penyelenggaraan SPS di Kota Banjarmasin agak berbeda dengan penyelenggaraan di daerah lain. Pendirian penyelenggaraan SPS di Kota Banjarmasin di sahkan oleh PKK Kelurahan setempat. Hal tersebut disebabkan penyelenggaraan SPS terintegrasi dengan Posyandu dan pengelola serta pendidik pada lembaga SPS berasal dari kader PKK, sehingga Ketua PKK kelurahan yang mengeluarkan Surat Keputusan tentang orang-orang yang menjadi pengelola dan pendidik di lembaga SPS yang bersangkutan. Namun untuk izin operasional tetap pada dinas pendidikan setempat.

Pelaksanaan monitoring dan evaluasi (monev) kepada lembaga SPS yang melakukan adalah PKK kelurahan, bukan dinas pendidikan (Disdik) Kota Banjarmasin. Selama ini lembaga PAUD yang mendapat bantuan dari pusat, pihak dinas pendidikan tidak tahu karena bantuan tersebut langsung diberikan pada lembaga bersangkutan melalui rekening lembaga dan mereka tidak memberikan informasi pada pihak dinas, sehingga ketika ada monev dari pusat, disdik agak kewalahan karena tidak tahu tentang hal tersebut.

Pada umumnya lembaga SPS yang ada di Kota Banjarmasin tidak ada yang bertahan lama dalam menyelenggarakan layanan PAUD. Hal tersebut disebabkan dalam 
penyelenggaraan SPS tidak ada pungutan sama sekali alias gratis, selain itu tidak ada pembinaan dari dinas pendidikan setempat sehingga begitu dapat bantuan dan habis masa bantuan tersebut, maka mereka tidak kewalahan untuk pembiayaan operasional selanjutnya. Lembaga SPS yang bertahan dikarenakan para kadernya memiliki tekad yang kuat untuk memberikan layanan pendidikan pada anak usia dini yang ada di sekitar lembaga mereka, sehingga untuk menutupi biaya operasional penyelenggaraan SPS ditanggung oleh pengelola dan para pendidik di lembaga itu. Pada Tabel 1 berikut merupakan data lembaga PAUD yang terdapat di Kota Banjarmasin pada tahun 2014.

Tabel 1. Jumlah Lembaga PAUD dan Peserta Didik Tahun 2014 berdasarkan Jenis Satuan PAUD

\begin{tabular}{|l|l|r|r|}
\hline No. & Jenis Satuan PAUD & Jumlah Lembaga & Jumlah Siswa \\
\hline 1. & TK & 311 & 9.860 \\
\hline 2. & KB & 140 & 1.686 \\
\hline 3. & TPA & 46 & 391 \\
\hline 4. & SPS & 12 & 80 \\
\hline \multicolumn{2}{|c|}{ Jumlah } & $\mathbf{5 0 9}$ & $\mathbf{1 2 . 0 1 7}$ \\
\hline
\end{tabular}

Sumber: Data Dinas Pendidikan Kota Banjarmasin Tahun 2014.

\section{Perencanaan di tingkat Dinas Pendidikan} Kota Banjarmasin

Pada perencanaan di tingkat Disdik Kota Banjarmasin yang akan di bahas adalah analisis tingkat keterpenuhan legalitas kelembagaan, analisis kebutuhan pendidikan untuk anak usia dini, dan analisis ketersediaan instrumental input dibanding kebutuhan yang terdiri dari: pendidik, sarana prasarana, dan dana. Namun demikian pada analisis ketersediaan instrumental inputi hanya sarana prasarana saja yang akan dibahas.

Analisis tingkat keterpenuhan legalitas kelembagaan yang akan diuraikan yaitu, persyaratan pendirian lembaga PAUD dan Persyaratan pemberian ijin operasional dari dinas Pendidikan. Untuk izin pendirian PAUD ada 14 item persyaratan yang harus dipenuhi oleh lembaga PAUD sesuai dengan juknis penyelenggaraan PAUD dari pusat. Sedangkan untuk izin operasional dari disdik persyaratan yang harus dipenuhi ada 26 persyaratan yaitu: 1) Proposal, 2) Profil Sekolah, 3) Surat Permohonan dari yayasan diketahui oleh penilik/pengawas, 4) Surat Rekomendasi dari Unit Pendidikan Kecamatan (UPTD), 5) Surat Rekomendasi Camat, 6) Foto Copy Akta Notaris, 7) Foto Copy sertifikat tanah/surat keterangan keadaan tanah, 8) Status gedung yang dimiliki dikuatkan surat keterangan dari RT, 9) Daftar Sarana dan Prasarana, 10) Daftar guru/staf beserta photo copy ijazah, SK honor mengajar 
serta photo copy NUPTK, 11) Daftar gaji guru dan staf, 12) Surat pernyataan kesanggupan membayar gaji guru dari yayasan, 13) Daftar jumlah murid, 14) Penghasilan/pendanaan sekolah, 15) Kurikulum yang digunakan (Lampirkan), 16) Visi dan Misi sekolah, 17) Program jangka pendek dan menengah, 18) Struktur organisasi yayasan dan struktur organisasi sekolah, 19) Bukti fisik kegiatan sekolah (foto kegiatan), 20) Fotocopy KTP/SIM Pimpinan yayasan, 21) Perjanjian kontrak kerja guru dan yayasan, 22) Fotocopy rekening bank atas nama sekolah dan NPWP nama sekolah, 23) Denah lokasi sekolah, 24) Kerjasama dengan pihak lain (jika ada), 25) Fotocopy sertifikat akreditasi, 26) Fotocopy ijin operasional. Ada catatan yang harus dipenuhi untuk mendapatkan izin operasional yaitu, 1) Memiliki jazah minimal Sekolah Menengah Atas (SMA) atau sederajat dan memiliki pelatihan/pendidikan/kursus PAUD yang terakreditasi bagi yang ijazah yang tidak relevan, 2) Minimal 1 (Satu) orang berpendidikan D-II PGTK/Kependidikan, 3) Apabila berdekatan dengan sekolah lain maka harus ada ijin tertulis di atas materai dari sekolah tersebut, 4) Sudah satu tahun ajaran menyelenggarakan PAUD, 5) Tempat pembelajaran tidak dihuni, memiliki halaman serta ruang belajar yang sehat, 6) Usia pendidik minimal 60 (enam puluh) tahun.

Menurut Disdik belum semua lembaga PAUD memiliki izin operasional, dari 509 lembaga PAUD yang sudah memiliki izin sebanyak 450 lembaga sisanya 59 lembaga lagi belum memiliki izin. Alasan lembaga yang belum memiliki izin operasional ada yang masih dalam proses tetapi ada pula yang memang belum mengajukan karena masih ada persyaratan yang belum dapat dipenuhi. Mekanisme perizinan yaitu pihak lembaga PAUD mengajukan permohonan izin operasional ke Disdik Kecamatan kemudian disampaikan ke Disdik Kota Banjarmasin, kemudian Disdik Kota Banjarmasin menelaah berkas yang masuk. Setelah itu disdik melakukan verifikasi lalu memberikan rekomendasi, lalu mengeluarkan izin sesuai SK yang telah ditetapkan. Untuk verifikasi ke lembaga yang mengajukan izin biasanya disisipkan pada kegiatan lain karena tidak ada anggaran untuk verfikasi.

Untuk analisis kebutuhan anak usia dini, ternayata disdik Kota Banjarmasin belum melakukan pendataan anak usia dini berdasarkan usia yang ada adalah total jumlah anak usia dini yang ada di wilayah Kota Banjarmasin yakni 82.718 anak. Jumlah peserta didik yang terdapat di lembaga PAUD secara keseluruhan yaitu 12.017 anak. Jadi jumlah anak usia dini yang baru terlayani oleh lembaga PAUD sebanyak 14,53 persen, masih 85,47 persen anak usia dini (70.701 anak usia dini) yang ada di Kota Banjarmasin belum mendapatkan layanan PAUD. Masih banyak pekerjaan bagi disdik Kota Banjarmasin agar semua anak usia dini dapat mendapatkan layanan PAUD.

Selain itu Disdik Kota Banjarmasin juga tidak melakukan pendataan pasangan usia 
subur dan anak remaja usia 15-20 tahun, mereka merupakan sumber penghasil anak usia dini di masa yang akan datang. Padahal dengan melakukan pendataan jumlah anak usia dini di masa yang akan datang dapat diprediksi dan dapat ditercukupi atau tidak dengan jumlah lembaga PAUD yang ada saat ini.

Untuk analisis kebutuhan intrumental input berupa sarana dan prasarana, Disdik Kota Banjarmasin juga tidak melakukan pendataan pada setiap lembaga PAUD yang ada di wilayahnya. Namun demikian, ada alokasi bantuan dari APBD Kota Banjarmasin untuk kebutuhan sarana dan prasarana walaupun jumlah kuotanya tidak memadai dengan jumlah lembaga PAUD yang ada seperti bantuan APE Dalam atau Luar, meubelair seperti meja dan kursi peserta didik. Selain itu ada juga bantuan ruang kelas baru dan renovasi ringan untuk kelas yang rusak ringan. Bantuan yang diberikan pada lembaga PAUD bukan berupa uang melainkan barang. Karena kuotanya tidak sesuai dengan jumlah lembaga PAUD yang ada maka bantuan dari Disdik diberikan secara bergantian.

\section{Perencanaan di tingkat Lembaga PAUD}

Pembahasan yang akan diuraikan pada perencanaan ditingkat lembaga PAUD sama dengan yang di Disdik Kota Banjarmasin. Untuk analisis keterpenuhan legalitas kelembagaan, belum semua lembaga PAUD sampel memiliki izin operasional. Untuk lembaga PAUD sampel yang sudah memiliki izin operasional sebanyak 4 lembaga (2 TK, 1 KB, 1 SPS), dua lembaga lainnya belum memiliki izin operasional yaitu satu lembaga SPS dan satu lembaga KB.

Persyaratan perizinan pendirian PAUD yang dapat dipenuhi oleh lembaga PAUD sampel sepenuhnya yaitu memiliki rekening Bank atas nama lembaga PAUD. Sedangkan lembaga $\mathrm{KB}$ tidak memenuhi persyaratan berikut, memiliki prospek peserta didik usia 0 -6 tahun paling sedikit 15 peserta didik dan memiliki sekurang-kurangnya 1 (satu) kelompok usia (4-5 tahun atau 5-6 tahun) dengan sekurang-kurangnya 20 orang anak didik karena bukan persyaratan untuk KB. Menurut dua pengelola SPS (33,33\%) persyaratan yang dirasakan paling sulit untuk dipenuhi adalah tenaga pendidik yang belum $\mathrm{S} 1$, sarana dan prasarana yang belum lengkap, masalah pendanaan karena tidak ada donatur. Selain itu yang menjadi beban yaitu untuk membuat akta notaris karena tidak adanya biaya yang dimiliki lembaga SPS, karena dalam penyelenggaraannya mereka tidak memungut dana pada orang tua siswa (gratis).

Mekanisme untuk proses pendirian lembaga PAUD adalah sebagai berikut. Lembaga PAUD dapat mengajukan izin pendirian dan operasional setelah menyelenggarakan layanan selama dua tahun. Langkah pertama, pihak lembaga datang ke Disdik Kota Banjarmasin untuk menanyakan persyaratan-persyaratan pendirian dan operasional PAUD. Kedua, setelah memenuhi 
persyaratan-persyaratan yang diminta (izin pendirian ada 14 item dan izin operasional ada 26 item yang harus dipenuhi), maka lembaga PAUD dapat mengajukan proposal ke disdik Kota Banjarmasin. Ketiga, Disdik Kota Banjarmasin menelaah proposal yang masuk, kemudian melakukan verifikasi dengan cara berkunjung ke lembaga PAUD yang mengajukan permohonan perizinan.

Keempat, Disdik Kota Banjarmasin mengeluarkan SK Pendirian atau Operasional lembaga PAUD. Proses perizinan tersebut membutuhkan waktu selama tiga bulan sampai SK keluar dari Disdik Kota Banjarmasin. Pada saat verifikasi menurut 50 persen pengelola, Disdik tidak menggunakan format khusus hanya pengecekan sesuai proposal yang diajukan. Sedangkan menurut 50 persen lagi pengelola mengatakan bahwa ada format khusus yang digunakan saat pelaksanaan verifikasi ke lembaga yang mengajukan perizinan.

Lembaga SPS berdiri karena adanya program Posyandu dan kegiatan PKK. Oleh karenanya izin pendirian berupa SK ditandatangani oleh ketua Tim Penggerak PKK kelurahan setempat. Untuk izin operasional baru lembaga SPS mengajukan kepada Disdik Kota Banjarmasin dan yang menjadi kendala dalam memperoleh izin operasional yaitu pembuatan akte notaris. Biaya yang dikeluarkan untuk pembuatan akte notaris berkisar Rp 600.000 sampai Rp 2 juta, bagi lembaga yang memiliki pendanaan besar hal tersebut tidak menjadi masalah, tetapi bagi lembaga PAUD yang tidak memiliki sumber dana itu menjadi masalah.

Analisis kebutuhan pendidikan untuk anak usia dini ternyata tidak dilakukan oleh lembaga PAUD sampel. Mereka mendapatkan data anak usia dini dari Posyandu ketika kegiatan Posyandu diselenggarakan. Data anak usia dini yang mereka miliki adalah data anak usia dini yang menjadi peserta didik saja, tidak melakukan pendataan anak usia dini yang ada di lingkungan sekitar. Begitu pula dengan keberadaan pasangan usia subur dan anak remaja usia 15-20 tahun, lembaga PAUD sampel tidak melakukan pendataan. Hal tersebut dikarenakan ketidak pahaman pengelola dalam memproyeksikan anak usia dini yang akan diperoleh lembaga PAUD mereka di tahun-tahun selanjutnya. Selain itu dimungkinkan karena merasa tidak diperlukan maka mereka tidak melakukan pendataan.

Analisis ketersediaan instrumental input pada lembaga hanya membahas masalah sarana dan prasarana yang terdapat di lembaga PAUD sampel. Ada enam persyaratan untuk pengadaaan sarana dan prasarana yang harus dipenuhi oleh lembaga PAUD. Untuk KB hampir semua persyaratan dapat terpenuhi, hanya di persyaratan Luas lahan/tanah yang dimiliki sekurang-kurangnya $300 \mathrm{~m}^{2}$ baru 50 persen terlaksana. Artinya ada satu lembaga KB yang memiliki luas lahan/tanah tidak mencapai $300 \mathrm{~m}^{2}$. Untuk TK, persyaratan yang belu dapat terpenuhi seluruhnya selain luas lahan/tanah minimal $300 \mathrm{~m}^{2}$ persyaratan memiliki ruang bermain/ruang belajar dengan 
rasio sekurang- kurangnya $3 \mathrm{~m}^{2}$ per anak, baik di dalam ataupun di luar ruangan. Hal tersebut mengindikasikan bahwa di TK masih ada lembaga yang tidak memiliki luas lahan minimal $300 \mathrm{~m}^{2}$ sama dengan KB. Sedangkan untuk lembaga SPS barus dua persyaratan yang dapat terpenuhi seluruhnya dari enam persyaratan yang harus dipenuhi yaitu, memiliki perabot, alat pengadaan alat permainan di luar dan di dalam ruangan serta Memiliki tempat untuk memajang hasil karya anak yang ditata sejajar dengan pandangan anak, leluasa, tidak terlalu penuh dengan alat permainan (masih ada ruang kosong untuk gerak anak). Selebihnya hanya sebagian lembaga saja yang dapat memenuhinya (50\%).

Menurut pengelola PAUD sampel mereka memiliki perencanaan sumber daya manusia (SDM), sarana prasarana (sarpras), kurikulum, dan pembiayaan. Untuk perencanaan pembelian sarpras semua lembaga PAUD sampel memilikinya, sedangkan perencanaan penambahan sarpras baru di tahun ajaran baru hanya 50 persen lembaga SPS yang memiliki, dan perencanaan pemeliharaan sarpras baru 50 persen lembaga KB yang memiliki.

Pada Grafik 1 di bawah ini untuk ruang administrasi, ruang kepala sekolah/pengelola dan ruang tidur/istirahat Lembaga KB dan SPS tidak memiliki. Untuk ruang belajar/bermain dalam (kelas) semua lembaga memilikinya, sedangkan untuk ruang lainnya sebagian lembaga PAUD sampel yang memilikinya yakni 50 persen (1 lembaga dari masingmasing satuan jenis PAUD).

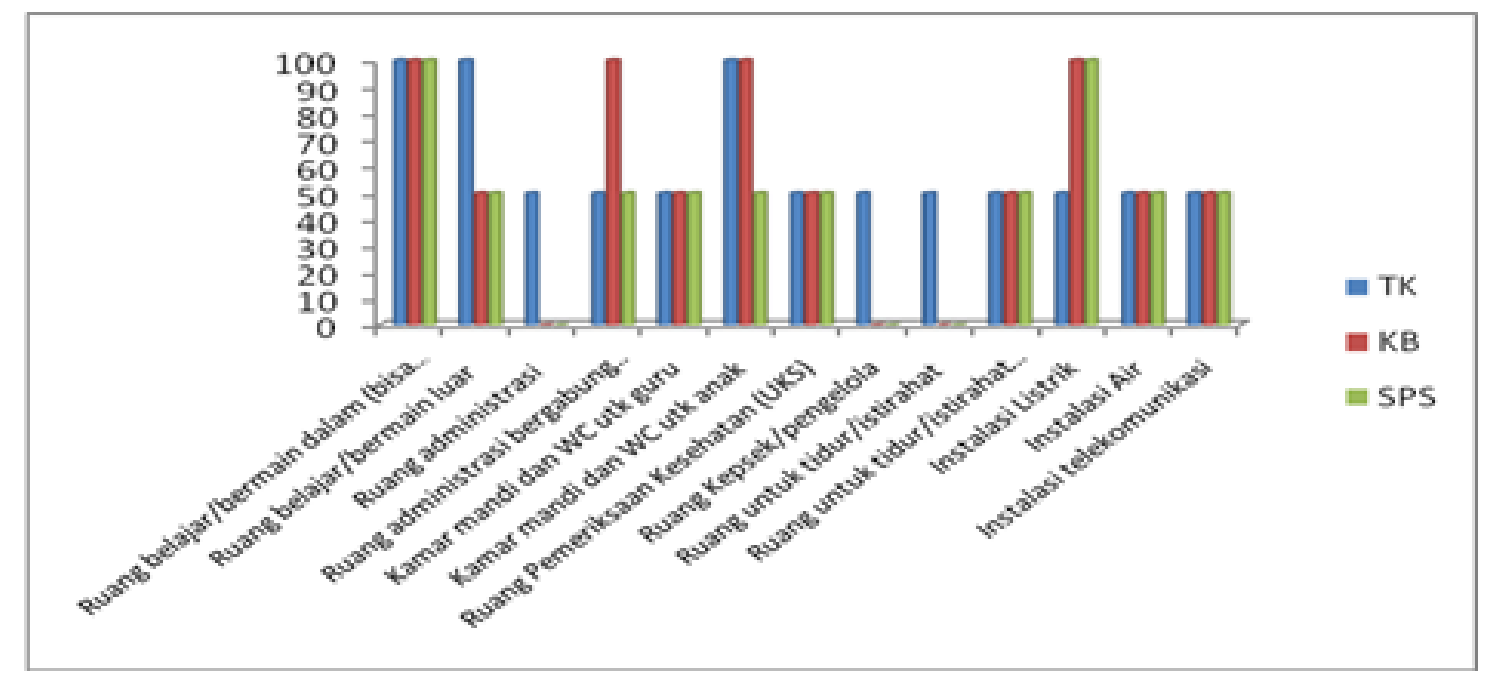

Grafik 1. Persentase Pemenuhan Kepemilikan Prasarana Utama Lembaga PAUD sampel.

Jika disesuaikan dengan prasarana yang terdapat dalam pedoman prasarana PAUD dari Direktorat Pembinaan PAUD, nampak terlihat bahwa belum semua lembaga PAUD sampel dapat memenuhi ketersediaan prasarana utama. Artinya dalam penyelenggaraan PAUD 
masih perlu adanya bantuan dari pusat, demi meningkatkan penyelenggaraan PAUD. provinsi, kabupaten/kota, dan masyarakat (Grafik 2).

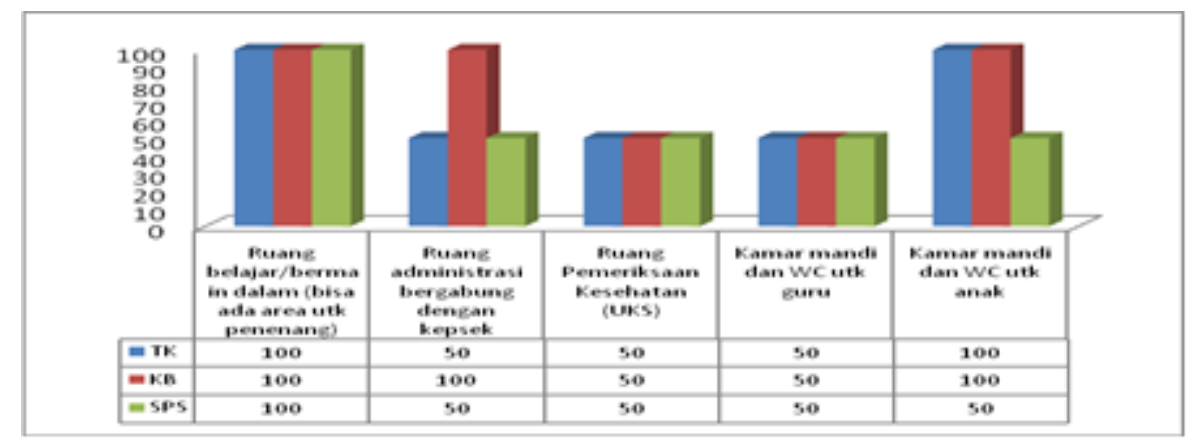

Grafik 2. Persentase keberadaan prasarana utama oleh lembaga PAUD sesuai pedoman prasarana PAUD

Sarana utama yaitu tempat cuci tangan dan rak untuk menata mainan hanya dipenuhi oleh satu lembaga TK. Tempat cuci tangan dan kursi anak dipenuhi oleh satu lembaga KB, sedangkan pemenuhan meja dan kursi anak serta jam dinding hanya dicapai oleh satu lembaga SPS saja. Pada lembaga SPS dan KB mengindikasikan bahwa proses pembelajaran dilakukan di lantai menggunakan karpet atau tikar. Namun demikian lembaga SPS nampaknya lebih fokus pada kebersihan dan menjaga kesehatan anak, terbukti dengan kepemilikan tempat cuci tangan dan rak tempat menata mainan semua lembaga SPS sampel memilikinya. (Grafik 3)

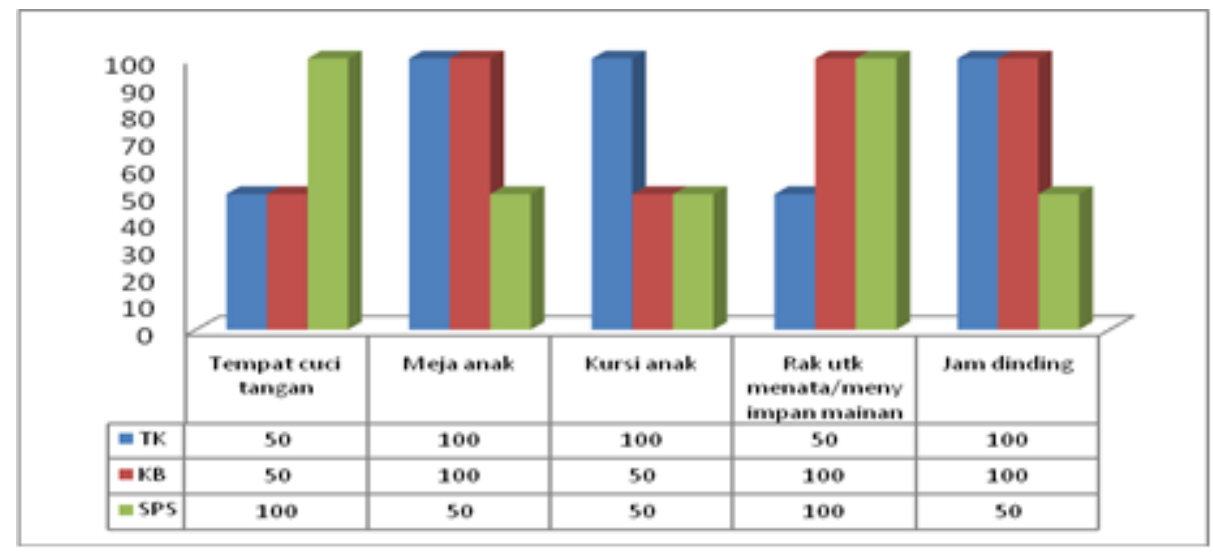

Grafik 3. Persentase Keberadaan Sarana Utama oleh Lembaga PAUD sampel

Untuk sarpras penunjang belum semua lembaga PAUD dapat memenuhi juga, yang dapat terpenuhi baru ketersediaan loker terbuka/tertutup. Untuk kantin yang memiliki hanya satu lembaga SPS, begitu pula dengan ketersediaan ruang tunggu orang tua peserta didik. Ruang konsultasi, ruang ibadah, dan ruang serbaguna/aula lembaga $\mathrm{KB}$ sampel 
tidak memiliki sama sekali. Pada umumnya mereka tidak memiliki secara keseluruhan jenis sarpras utama dan penunjang karena ketersediaan lahan dan dana yang dimiliki oleh lembaga. Untuk mengetahui lebih jelas persentase ketersediaan prasarana penunjang dapat dilihat pada grafik berikut ini.

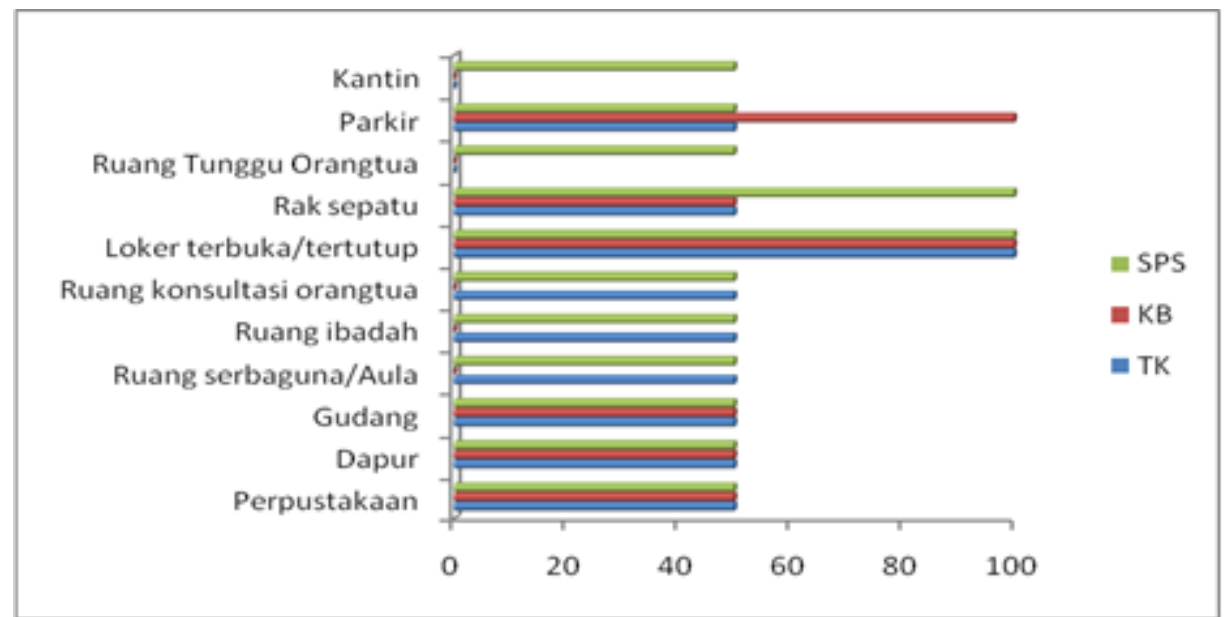

Grafik 4. Persentase keberadaan Prasarana Penunjang Oleh Lembaga PAUD sampel

Sarana pembelajaran terdiri dari dua bagian yaitu media pembelajaran dan sumber belajar. Untuk media pembelajaran TK dan KB tidak memiliki papan geometri. Semua lembaga $\mathrm{KB}$ sampel sudah memiliki media pembelajaran kecuali papan geometri tadi. Sedangkan untuk lembaga TK dan SPS belum semua lembaga memiliki semua media pembelajaran. (Grafik 5)

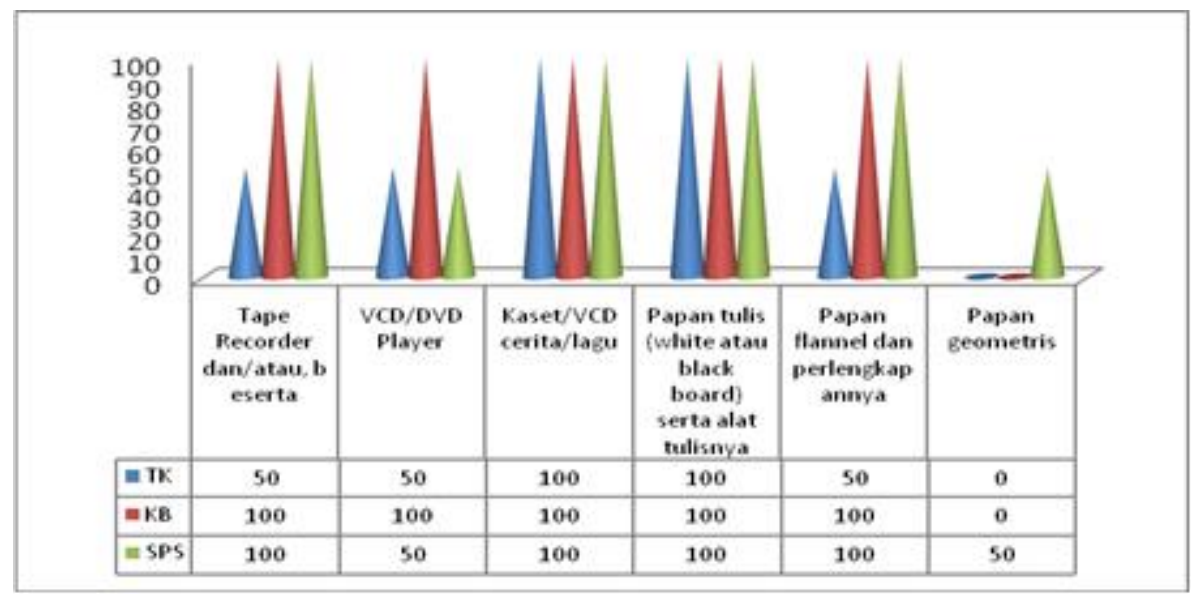

Grafik 5. Persentase keberadaaan Media Pembelajaran yang terdapat pada lembaga PAUD sampel.

Sumber belajar terdiri dari buku-buku yang digunakan sebagai referensi atau sekedar buku bacaan saja. Buku cerita anak, buku bergambar anak, dan kamus sudah dimiliki oleh semua lembaga PAUD sampel. Buku ensiklopedia tidak dimiliki oleh lembaga SPS 
sampel. Hal tersebut dimungkinkan karena buku tersebut mahal harganya dan dirasakan kurang bermanfaat sehingga tidak dimiliki oleh lembaga SPS sampel. Selain itu belum semua lembaga TK, KB, dan SPS memiliki majalah anak walaupun sekedar untuk bahan bacaan. Hal tersebut dimungkinkan karena untuk membuat majalah anak butuh keahlian khusus dan walaupun membeli terkait kembali pada dana yang dimiliki oleh lembaga serta kebermanfaatannya. (Grafik 6)

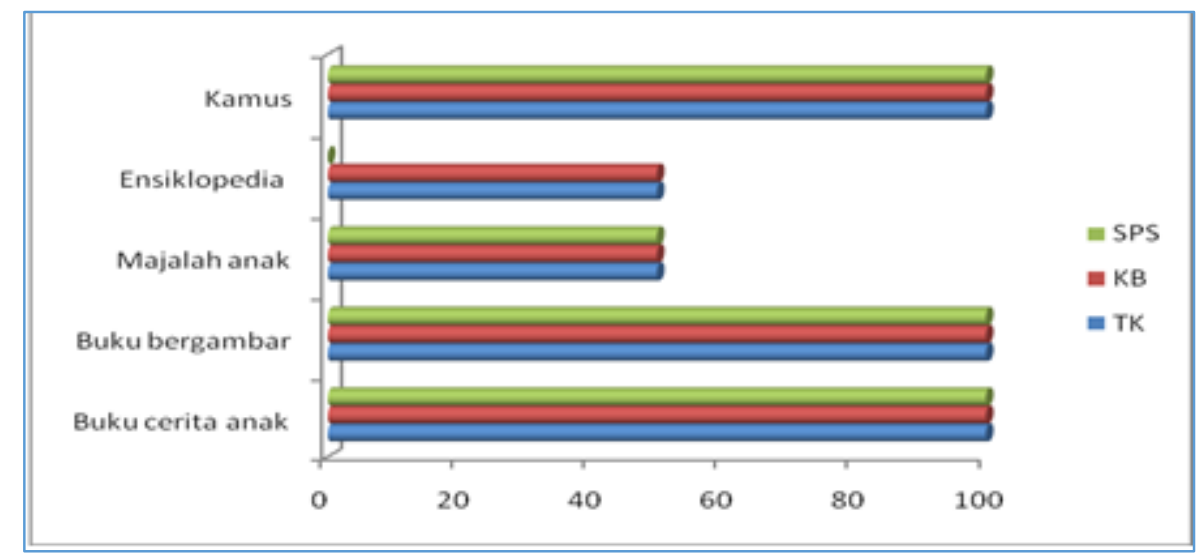

Grafik 6. Persentase Keberadaan Sumber Belajar di Lembaga PAUD sampel

Berdasarkan buku pedoman sarana PAUD dari Direktorat Pembinaan PAUD ada 26 APE Dalam yang harus disediakan oleh lembaga PAUD. Dari 26 jenis APE Dalam yang dapat dipenuhi secara lengkap oleh lembaga PAUD sampel hanya lima jenis, yaitu puzzle, buku bergambar, roncean, cermin/kaca, dan bahan limbah yang layak dan aman bagi peserta didik. Jika dilihat dari segi pembiayaan kelima APE dalam tersebut harganya tidak mahal dan mudah didapat. Hal ini mengindikasikan bahwa lembaga PAUD sampel belum dapat menyediakan semua jenis APE Dalam karena dana yang dimiliki tidak memadai.

Sedangkan untuk APE Luar ada 15 jenis, tetapi ada lembaga KB dan SPS yang tidak memiliki ke 15 jenis APE Luar. Untuk TK sebagian sudah memiliki APE Luar lengkap, namun demikian, Lembaga $\mathrm{KB}$ ada yang tidak memiliki jaring laba-laba, gawang bola, terowongan dari semen yang dibeton, dan matras/kasur. Sedangkan lembaga SPS tidak memiliki APE Luar seperti jaring laba-laba, terowongan dari semen yang dibeton, matras/kasur, ayunan, mainan yang dapat didorong, dan sepeda dengan pegangan. APE Luar yang terdapat di semua lembaga PAUD yaitu mobil-mobilan yang dikendarai anak. Hal tersebut mengindikasikan bahwa untuk menyediakan APE Luar tidak semua lembaga PAUD dapat melaksanakannya, dikarenakan dana yang dimiliki oleh lembaga PAUD bervariasi dan prioritas pembelian dengan memperhatikan pemanfaatan dari APE Luar. 


\section{Upaya Disdik Kota Banjarmasin dalam} Mengatasi Masalah Perizinan dan Ketersediaan Sarana Prasarana

Selama ini pemerintah pusat sudah berusaha memberikan bantuan kepada lembaga PAUD seperti bantuan rintisan PAUD, kelembagaan, PAUD unggulan, BOP, dan masih banyak yang lainnya. Namun karena setiap tahunnya jumlah lembaga PAUD makin meningkat sehingga bantuan yang diberikan masih belum dapat memadai untuk semua lembaga PAUD yang ada. Oleh sebab itu pemerintah pusat meminta pendampingan pada pemerintah daerah khsusunya kabupaten/kota untuk memberikan bantuan kepada lembaga PAUD yang tidak mendapat bantuan dari pusat.

Upaya disdik Kota Banjarmasin untuk masalah perizinan yakni dengan cara mempermudah proses perizinan baik dari segi persyaratan dan waktu. Sedangkan untuk masalah sarana dan prasarana, upaya yang dilakukan disdik yaitu meningkatkan jumlah alokasi bantuan dan besarannya.

\section{SIMPULAN DAN SARAN}

\section{Simpulan}

\section{Ditingkat Disdik Kabupaten/Kota}

Disdik Kota Banjarmasin tidak melakukan perencanaan dalam penyelenggaraan PAUD di wilayahnya. Hal tersebut diperkuat dengan tidak adanya pendataan pasangan usia subur dan anak remaja usia 15-20 tahun. Data anak usia dini yang terlayani lembaga PAUD adanya juga data total, tidak ada data jumlah peserta didik berdasarkan jenis kelamin.

Untuk masalah izin operasional masih 11,59 persen lembaga PAUD belum memiliki izin tersebut. Hal tersebut disebabkan berbagai alasan, antara lain masih ada yang dalam proses, tetapi ada juga yang belum disebabkan untuk membuat akta notaris membutuhkan dana yang tidak sedikit. Sehingga hal tersebut menjadi kendala dalam proses izin operasional, selain itu masalah untuk mendapatkan pendidik sesuai standar PAUD. Umumnya pendidik lulusan S1 mau menjadi guru meminta gaji yang cukup besar, tetapi lembaga PAUD tidak memiliki dana untuk membayar gaji tersebut, sehingga lembaga mencari pendidik disesuaikan dengan kemampuan dana yang ada.

Disdik Kota Banjarmasin memberikan bantuan sarana prasarana kepada lembaga PAUD berupa ruang kelas baru, rehab ringan, rehab berat, dan APE Dalam/Luar. Namun bantuan tersebut belum dapat diberikan kepada semua lembaga PAUD yang ada di Kota Banjarmasin, kuota yang ada jumlahnya sedikit.

\section{Ditingkat Lembaga PAUD}

Lembaga PAUD sampel tidak melakukan perencanaan analisis kebutuhan pendidikan anak usia dini, karena tidak melakukan pendataan jumlah anak usia dini, pasangan usia subur, dan anak remaja usia 1520 tahun yang ada disekitar lembaga. Belum 
semua lembaga PAUD memiliki izin operasional dikarenakan ada persyaratan yang belum dapat dipenuhinya seperti akte notaris yang untuk membuatnya membutuhkan data yang cukup banyak. Selain itu belum semua lembaga PAUD sampel memiliki sarpras sesuai dengan pedoman sarana dan prasarana PAUD yang dikeluarkan oleh Direktorat Pembinaan PAUD. Hal tersebut karena pendanaan yang dimiliki lembaga PAUD bervariasi.

\section{Opsi Kebijakan}

Untuk mengetahui perkembangan lembaga PAUD di masa yang akan datang serta agar terjadi pemerataan lembaga PAUD dan jumlah anak usia dini, maka Disdik perlu melakukan perencanaan yang mencakup, analisis tingkat keterpenuhan legalitas kelembagaan, analisis kebutuhan pendidikan untuk anak usia dini, dan analisis ketersediaan intrumental input (sarpras).

Agar semua lembaga PAUD dapat memiliki izin operasional maka persyaratan yang begitu banyak dikurangi yang penting saja. Dan untuk pengadaan akte notaris perlu ada bantuan dari Disdik setempat bagi lembaga PAUD yang tidak mampu.

Untuk lembaga PAUD sebelum menyelenggarakan lembaga PAUD sebaiknya melakukan pendataan anak usia dini dan pasangan usia subur, agar dapat memproyeksikan anak usia dini yang dapat ditampung di lembaga PAUDnya. Untuk memenuhi sarpras pengelola dapat bekerjasama dengan pihak lain untuk mendapatkan bantuan, karena kalau mengharapkan bantuan dari pusat, provinsi, atau kabupaten/kota kuota yang ada sangat sedikit untuk sarpras 


\section{DAFTAR PUSTAKA}

Amandemen Undang-undang Dasar Republik Indonesia Tahun 1945 dalam http://jdih.ristek.go.id/?q=perundangan/konten/1828.

Arri Handayani, dkk, 2011. Peningkatan Kualitas Pos Paud Melalui Pengembangan Program Holistik Integratif (Penelitian Tindakan Pada Pos PAUD Se-Kalurahan Penggaron Kidul), dalam http://download.portalgaruda.org/article.php? article=6983\&val=530. Jurnal Penelitian PAUDIA, Volume 1 No.1, November 2011.

BPS Banjarmasin, 2015. Banjarmasin Dalam Angka 2015. BPS Kota Banjarmasin, 2015.

Direktorat Pembinaan PAUD, 2014. NSPK, Norma,Standar, Prosedur, dan Kriteria Pedoman Prasarana Pendidikan Anak Usia Dini, Direktorat Pembinaan PAUD, Jakarta, 2014.

Direktorat Pembinaan PAUD, 2014. NSPK, Norma,Standar, Prosedur, dan Kriteria Pedoman Sarana Pendidikan Anak Usia Dini, Direktorat Pembinaan PAUD. Jakarta, 2014.

Hiryanto, dkk. (tanpa tahun). Pemetaan Tingkat Pencapaian Mutu Program Pendidikan Anak Usia Dini (PAUD) Di Propinsi DIY, dalam http://staff.uny.ac.id/sites/default/files/ penelitian/Drs.\%20Hiryanto,\%20M.Si./artikel.Pemetaan\%20Tingkat\%20Pencapain\% 20Mutu\%20PAUD.pdf. Hasil Penelitian Research Grant Program Hibah Kompetisi (PHK) A-2 Prodi PLS

M.A. Mukhyi, (1991). Buku Seri Diklat Pengantar Manajemen Umum (Untuk STMIK), Gunadarma. Jakarta, 1991.

Manap Somantri, 2014. Buku Perencanaan Pendidikan dalam http://repository.unib.ac.id/8045/1/B12\%20Manap,\%202013\%20-\%20BUKU\%20. IPB Press, Bogor 2014.

Puslitjak, 2014. Efektifitas Kelembagaan Pendidikan Anak Usia Dini. Jakarta, 2014.

Peraturan Menteri Pendidikan dan kebudayaan Republik Indonesia Nomor 84 Tahun 2014 Tentang Pendirian Satuan Pendidikan Anak Usia Dini. Jakarta, 2015.

Sigit Dwi Handoko, 2014. Penyelenggaraan Program Di Pos Paud Cinta Ibu Di Desa Pangempon Kecamatan Bawang Kabupaten Batang, dalam http://journal.unnes.ac.id/sju/index.php/jnfc. Unes, Semarang 2014.

Undang-undang Republik Indonesia Nomo 20 Tahun 2003 Tentang Sistem Pendidikan Nasional, Departemen Pendidikan Nasional Republik Indonesia, Cetakan Ketiga. Jakarta, 2006. 